\title{
Precipitation model in microalloyed steels both isothermal and continuous cooling conditions
}

\author{
Sebastián F. Medina ${ }^{\mathrm{a}, \bowtie}$, Alberto Quispe ${ }^{\mathrm{b}}$, Manuel Gómez ${ }^{\mathrm{a}}$ \\ ${ }^{a}$ Centro Nacional de Investigaciones Metalúrgicas (CENIM) CSIC. Avda. Gregorio del Amo 8, 28040 Madrid, Spain \\ ${ }^{b}$ Universidad Jorge Basadre (UNJBG), Av. Miraflores s/n University City, Tacna, Perú \\ Corresponding author: smedina@cenim.csic.es
}

Submitted: 1 October 2015; Accepted: 1 November 2015; Available On-line: 13 November 2015

\begin{abstract}
Niobium and vanadium precipitates (nitrides and carbides) can inhibit the static recrystallization of austenite but this does not happen for Ti, which form nitrides at high temperatures. RPTT diagrams show the interaction between recrystallization and precipitation allowing study the strain induced precipitation kinetics and precipitate coarsening. Based on Dutta and Sellars's expression for the start of strain-induced precipitation in microalloyed steels, a new model has been constructed which takes into account the influence of variables such as microalloying element percentages, strain, temperature, strain rate and grain size. RecrystallizationPrecipitation-Time-Temperature (RPTT) diagrams have been plotted thanks to a new experimental study carried out by means of hot torsion tests on approximately twenty microalloyed steels with different $\mathrm{Nb}, \mathrm{V}$ and $\mathrm{Ti}$ contents. Mathematical analysis of the results recommends the modification of some parameters such as the supersaturation ratio $\left(\mathrm{k}_{\mathrm{s}}\right)$ and constant $\mathrm{B}$, which is no longer a constant but a function of $\mathrm{k}_{\mathrm{s}}$. The expressions are now more consistent and predict the Precipitation-Time-Temperature (PTT) curves with remarkable accuracy. The model for strain-induced precipitation kinetics is completed by means of Avrami's equation. Finally, the model constructed in isothermal testing conditions, it has been converted to continuous cooling conditions in order to apply it in hot rolling.
\end{abstract}

KEYWORDS: Austenite; Microalloyed steels; Model; Precipitation kinetics; Strain

Citation / Cómo citar este artículo: Medina, S.F., Quispe, A., Gómez, M. (2015) "Precipitation model in microalloyed steels both isothermal and continuous cooling conditions". Rev. Metal. 51(4): e056. doi: http://dx.doi.org/10.3989/ revmetalm.056.

RESUMEN: Modelo de precipitación en aceros microaleados tanto en condiciones isotérmicas como de enfriamiento continuo. Los precipitados de $\mathrm{V}$ y Nb (nitruros y carburos) pueden inhibir la recristalización estática de la austenita, pero no sucede lo mismo con el Ti que forma nitruros a altas temperaturas. Los diagramas RPTT muestran la interacción entre la recristalización y la precipitación, permitiendo estudiar la cinética de la misma y el crecimiento de los precipitados. Partiendo de la expresión de Dutta y Sellars se ha construido un modelo para la precipitación inducida por la deformación en aceros microaleados. El nuevo modelo toma en cuenta la influencia de las variables que intervienen en la deformación a alta temperatura, tales como los porcentajes de elementos microaleantes, la magnitud de la deformación, la temperatura, la velocidad de deformación y el tamaño de grano. Los diagramas Recristalización-Precipitación-TiempoTemperatura (RPTT) fueron dibujados gracias a un estudio realizado por medio de ensayos de torsión con aproximadamente 20 aceros con diferentes contenidos de V, Nb y Ti. El análisis matemático de los resultados recomienda, entre otros aspectos, la modificación de algunos parámetros tales como la relación de supersaturación $\left(\mathrm{k}_{\mathrm{s}}\right)$ y de la constante $\mathrm{B}$ que pasa a ser una función de $\mathrm{k}_{\mathrm{s}}$. El modelo es ahora más consistente y predice los diagramas Precipitación-Tiempo-Temperatura (PTT) con mayor exactitud. El modelo de cinética 
de precipitación es completado con la ecuación de Avrami. Finalmente, el modelo construido en condiciones isotérmicas es convertido a condiciones de enfriamiento continuo y de este modo puede ser aplicado a la laminación en caliente.

PALABRAS CLAVE: Aceros microaleados; Austenita; Cinetica de precipitacion; Deformacion; Modelo

Copyright: (C) 2015 CSIC. This is an open-access article distributed under the terms of the Creative Commons Attribution-Non Commercial (by-nc) Spain 3.0 License.

\section{INTRODUCTION}

The type and amount of microalloying elements play an important role on the shape and the nature of precipitates. However, the impact of some elements that are not considered as authentic microalloying elements is usually underestimated, even though the influence of these elements on chemical composition, size and distribution of precipitates can be even stronger than that of microalloying. This is true for aluminium-killed, V/Nb-microalloyed steels, whose $\mathrm{Al}$ content is often higher than 0.020 mass $\%$. VN particles and $\mathrm{NbCN}$ are finer than $\mathrm{AlN}$ and therefore they have a stronger contribution during hot rolling (Gómez et al., 2009). Fine VN and $\mathrm{NbCN}$ precipitates inhibit static recrystallization of austenite, which leads to austenite strengthening during last hot rolling passes. Besides, VN promotes intragranular nucleation of ferrite (Medina et al., 2008a). At equal level of $\mathrm{Nb}, \mathrm{Al}$, Ti or $\mathrm{V}$ alloying, the precipitates are soluble in austenite as follows (Turkdogan, 1989): $\mathrm{TiN}<\mathrm{AlN}<\mathrm{NbN}<\mathrm{VN}$. On the other hand the presence of $\mathrm{AlN}$ in the austenite generates harmful effects on the hot-ductility of different kinds of steels (Mintz and Arrowsmith, 1980).

Crystallographic structure of AlN is hexagonal (h.c.p.). Nitrides and carbides of typical microalloying elements $(\mathrm{Nb}, \mathrm{V}, \mathrm{Ti})$ have an f.c.c. crystallographic structure and frequently form precipitates which are semi-coherent with the austenitic (f.c.c) matrix. Lattice parameter is slightly higher than that of the austenite (Gladman, 1997).

When strain-induced precipitation starts in microalloyed steels, static recrystallization is inhibited for a certain time, normally until the end of precipitation, before proceeding until recrystallization is complete. It is well known that the static recrystallization of microalloyed steels is different before and after straininduced precipitation. Before, all the elements are in solution and recrystallization kinetics occur in the same way as in low alloy steels, whereby the various alloying elements contribute to delaying recrystallization to a greater or lesser degree (Andrade et al., 1983; Kwon, 1992). As the temperature drops, a critical temperature is reached, after which static recrystallization is momentarily inhibited by the effect of strain-induced precipitates. This momentary inhibition of recrystallization appears as a plateau on the recrystallized fraction versus time curves (Luton et al., 1980). When the end of the plateau is reached, recrystallization recommences as the coarsening of precipitates consequently reduces the pinning forces against driving forces. After the plateau, the superiority of driving forces for recrystallization over pinning forces is about two orders of magnitude. Good definition of the plateau allows the plotting of recrystallization-precipitation-time-temperature (RPTT) diagrams (Quispe et al., 1997; Gómez et al., 2005).

The most important reference to predict straininduced precipitation nucleation as a function of hot deformation variables (strain, strain rate, temperature) is perhaps the expression given by Dutta and Sellars for a time corresponding to $5 \%$ of the precipitated volume $t_{0.05}$, which in practical terms can be taken as the nucleation time for precipitation. The model was applied to Nb-microalloyed steels and takes into account the Nb-content, strain, strain rate and temperature (Dutta and Sellars, 1987).

In the present work, a precipitation model based on the above is proposed, taking into account the influence of variables such as microalloying element percentages, strain, temperature, strain rate and grain size, and new parameters and relationships are established. New adjustments have been made and in particular the influence of the temperature has been reassessed thanks to the performance of new calculations based on experimental results and new thermodynamic considerations. Although the model will be presented in its entirety, the quantitative influence of the aforementioned variables will simply be summarized, since the model has been recently published in its full version (Medina et al., 2014a; Medina et al., 2014b).

\section{MATERIALS AND EXPERIMENTAL PROCEDURE}

Nineteen steels were manufactured by Electroslag Remelting (ESR) in a laboratory unit capable of producing $30 \mathrm{~kg}$ ingots. The steels contained various combinations of carbon, nitrogen, and precipitate-forming elements such as $\mathrm{V}, \mathrm{Nb}$ and $\mathrm{Ti}$. Their compositions are listed in Table 1. Given that niobium nitrides, carbides and carbonitrides are less soluble in austenite than those of vanadium, the limit imposed on carbon and nitrogen contents was that the solubility temperature should not exceed $1300^{\circ} \mathrm{C}$.

Torsions specimens were prepared with a gauge length of $50 \mathrm{~mm}$ and a diameter of $6 \mathrm{~mm}$. The reheating temperature before torsion deformation varied 
according to whether the steel was microalloyed with $\mathrm{V}$ or $\mathrm{Nb}$, as the solubility temperature of the precipitates depends on their nature and on the precipitateforming element content. The parameters of torsion (torque, number of revolutions) and the equivalent parameters of tension (stress, strain) were related according to Von Mises criterion (Faessel, 1976).

For steels containing vanadium, designated by the letter $\mathrm{V}$, the reheating temperature was $1230^{\circ} \mathrm{C}$ for steels V1, V2 and V3 and $1200{ }^{\circ} \mathrm{C}$ for the rest, which is sufficient to dissolve vanadium nitrides and carbides. In the case of niobium steels, designated by the letter $\mathrm{N}$, the reheating temperature depended on the carbon, niobium and nitrogen contents, but was always above the solubility temperature of niobium carbonitrides (Turkdogan, 1989). Critical transformation temperatures $\left(\mathrm{A}_{\mathrm{r} 3}\right)$ were measured by dilatometry at a cooling rate of $0.2 \mathrm{~K} \mathrm{~s}^{-1}$ and in some cases by hot rolling simulation (Vega et al., 1999; Medina et al., 2000). Three of the steels contained $\mathrm{Ti}$, and it is well known that titanium nitrides do not completely dissolve at the reheating temperatures used (Medina and Mancilla, 1994).

TABLE 1. Chemical composition (mass \%), transformation critical temperature $\left(\mathrm{A}_{\mathrm{r} 3}\right.$, at $\left.0.2 \mathrm{~K} \mathrm{~s}^{-1}\right)$ and austenite grain size $\left(\mathrm{D}_{\gamma}\right)$ at reheating temperature (RT), being $\mathrm{X}_{\mathrm{i}}=\mathrm{V}, \mathrm{Nb}, \mathrm{Ti} \%$

\begin{tabular}{lccccccc}
\hline Steel & $\mathbf{C}$ & $\mathbf{S i}$ & $\mathbf{M n}$ & $\mathbf{A l}$ & $\mathbf{X}_{\mathbf{i}}$ & $\mathbf{N}$ & $\mathbf{A}_{\mathbf{r} 3},{ }^{\circ} \mathbf{C}$ \\
\hline V1 & 0.11 & 0.24 & 1.10 & 0.012 & $\mathrm{~V}=0.043$ & 0.0105 & 786 \\
V2 & 0.12 & 0.24 & 1.10 & 0.012 & $\mathrm{~V}=0.060$ & 0.0123 & 782 \\
V3 & 0.11 & 0.24 & 1.00 & 0.010 & $\mathrm{~V}=0.093$ & 0.0144 & 784 \\
V4 & 0.21 & 0.20 & 1.10 & 0.009 & $\mathrm{~V}=0.062$ & 0.0134 & 768 \\
V5 & 0.33 & 0.22 & 1.24 & 0.011 & $\mathrm{~V}=0.076$ & 0.0146 & 716 \\
V6 & 0.35 & 0.21 & 1.23 & 0.008 & $\mathrm{~V}=0.033$ & 0.0121 & 715 \\
V7 & 0.42 & 0.24 & 1.32 & 0.012 & $\mathrm{~V}=0.075$ & 0.0200 & 718 \\
V8 & 0.37 & 0.24 & 1.42 & 0.012 & $\mathrm{~V}=0.120$ & 0.0190 & 721 \\
TV1 & 0.55 & 0.29 & 1.06 & 0.000 & $\mathrm{~V}=0.063$ & 0.0174 & 693 \\
& & & & & $\mathrm{Ti}=0.019$ & & \\
TV2 & 0.34 & 0.22 & 1.08 & 0.009 & $\mathrm{~V}=0.055$ & 0.0182 & 718 \\
N1 & 0.11 & 0.24 & 1.23 & 0.002 & $\mathrm{Nb}=0.041$ & 0.0112 & 786 \\
N2 & 0.11 & 0.24 & 1.32 & 0.002 & $\mathrm{Nb}=0.093$ & 0.0119 & 786 \\
N3 & 0.21 & 0.18 & 1.08 & 0.007 & $\mathrm{Nb}=0.024$ & 0.0058 & 768 \\
N4 & 0.21 & 0.19 & 1.14 & 0.008 & $\mathrm{Nb}=0.058$ & 0.0061 & 769 \\
& & & & & & & \\
N5 & 0.51 & 0.25 & 1.20 & 0.008 & $\mathrm{Nb}=0.026$ & 0.0105 & 674 \\
N7 & 0.29 & 0.22 & 1.30 & 0.006 & $\mathrm{Nb}=0.066$ & 0.0062 & 751 \\
N8 & 0.20 & 0.20 & 1.0 & 0.006 & $\mathrm{Nb}=0.007$ & 0.0056 & 770 \\
N9 & 0.46 & 0.24 & 1.25 & 0.011 & $\mathrm{Nb}=0.009$ & 0.0100 & 704 \\
TN1 & 0.21 & 0.22 & 1.18 & 0.007 & $\mathrm{Nb}=0.028$ & 0.0060 & 768 \\
\hline & & & & & $\mathrm{Ti}=0.024$ & & \\
\hline
\end{tabular}

In all cases the testing temperatures $\left(1150-850{ }^{\circ} \mathrm{C}\right)$ were set as the recrystallized fraction was determined and the recrystallized fraction curves drawn, so that the curves finally obtained would include curves where strain-induced precipitation had taken place and curves where it had not, as is discussed below. The recrystallized fraction $\left(X_{a}\right)$ was determined using the "back extrapolation" method (Andrade et al., 1983; Pertula and Karjalainen, 1998). The study of precipitates was carried out using Transmission Electron Microscopy (TEM). The microalloyed steels are also known as high strength low alloy (HSLA) steels (Galán et al., 2012).

\section{EXPERIMENTAL RESULS}

\subsection{Static recrystallization curves and RPTT diagrams}

The recrystallized fraction, determined by applying the back extrapolation method, was drawn against time for each testing temperature. The shape of the recrystallized fraction versus time curves were similar for all the $\mathrm{V}$ microalloyed steels, it being observed that some curves display a plateau caused by the formation of precipitates which momentarily inhibit the progress of recrystallization (Fig. 1). The plateau is caused by strain-induced precipitation, as occurs in all microalloyed steels. While the start of the plateau seems to coincide with good exactness with the start of strain-induced precipitation, the end of the plateau may coincide with important growth in the average size of precipitates, which become incapable of inhibiting recrystallization (Kwon and DeArdo 1991). The curves corresponding to higher temperatures than those mentioned have the sigmoidal shape of Avrami's law. Furthermore, the plateau is not unlimited, i.e., precipitation does not permanently inhibit recrystallization, and recrystallization

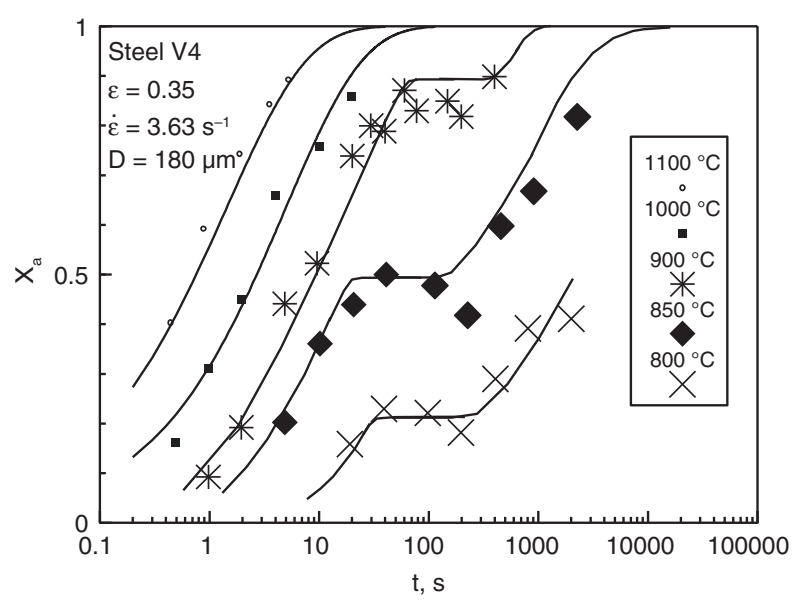

FIGURE 1. Variation of recrystallized fraction $\left(\mathrm{X}_{\mathrm{a}}\right)$ with time (t) for steel V4. 
again progresses until is complete, following a graphic plot similar to that recorded before the formation of the plateau. With regard to the steels containing titanium, their behaviour was like that of the vanadium steels.

The $\mathrm{Nb}$ microalloyed steels showed varying behaviour. Some presented a similar plateau to the $\mathrm{V}$ steels as in the case of steels N1, N2, N3, N8 and N9. An example of which is shown for steel N8 in Fig. 2. However, other steels, such as N4, N5 and N7, presented a double plateau. This phenomenon is due to the formation of two types of carbonitrides which start to form at practically the same temperature but the second precipitation is promoted by the first when the nitrogen or carbon content is reduced (Medina et al., 1999; Gómez et al., 2002).

The recrystallized fraction versus time curves were used to plot Recrystallization-PrecipitationTime-Temperature (RPTT) diagrams. The points defining the start and the end of the plateau were taken to plot the curves for the start $\left(\mathrm{P}_{\mathrm{s}}\right)$ and the end $\left(\mathrm{P}_{\mathrm{f}}\right)$ of precipitation, respectively. Figs. 3 and 4 are

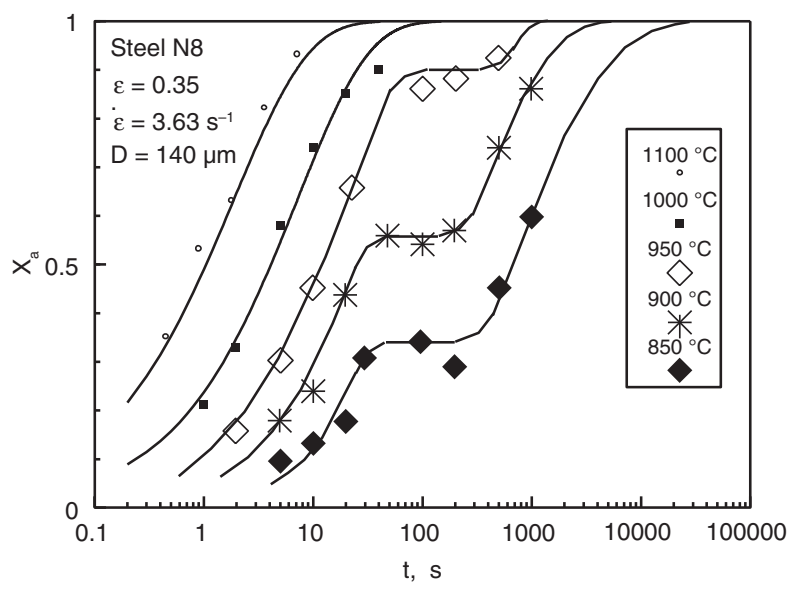

Figure 2. Variation of recrystallized fraction $(\mathrm{Xa})$ with time $(\mathrm{t})$ for steel N8.

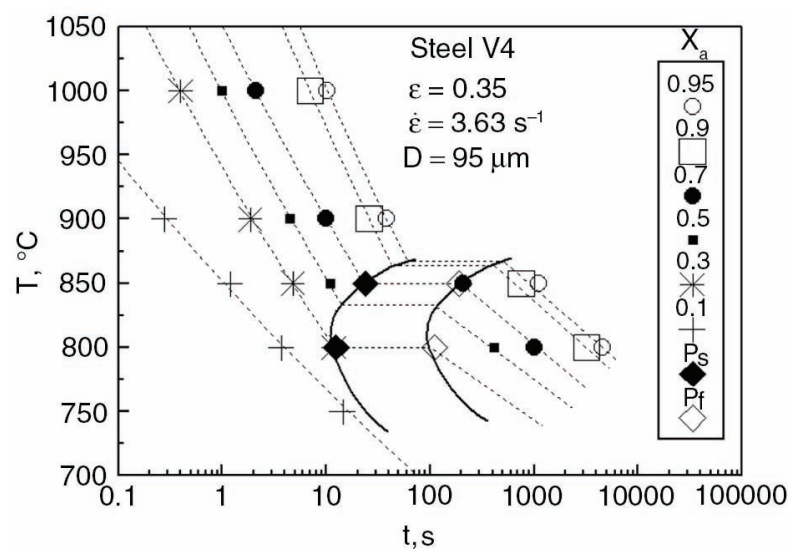

FIGURE 3. RPTT diagram for steel V4.

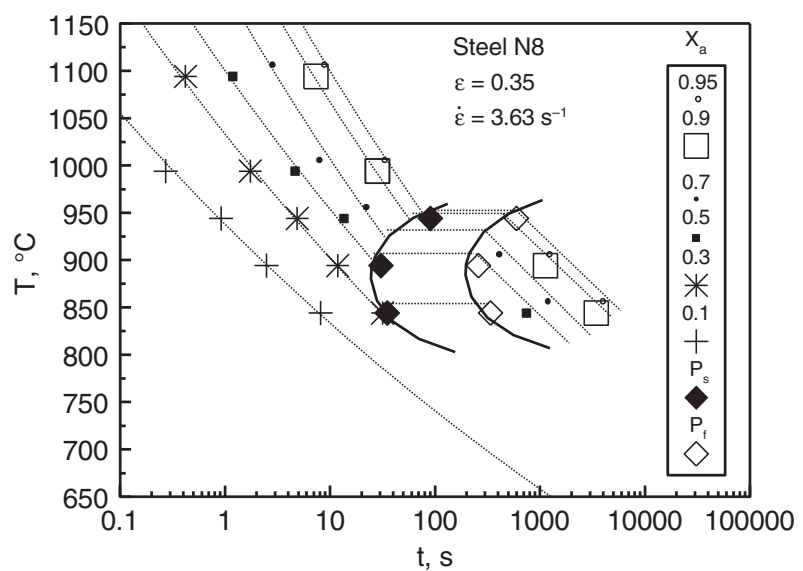

FIGURE 4. RPTT diagram for steel N8.

two examples corresponding to steels V4 and N8, respectively. With regard to the recrystallizationprecipitation interaction, it is seen that at the nose of the $\mathrm{P}_{\mathrm{s}}$ curve, where the incubation time of the precipitates $\left(t_{N}\right)$ is minimal, the recrystallized volume fraction is approximately $50 \%$. When the recrystallized volume fraction $\left(\mathrm{X}_{\mathrm{a}}\right)$ is less than $20 \%$, the nucleation of the precipitates is very difficult, even though the dislocation density increases with the decrease in $X_{a}$. This is due to the drop in diffusivity with the temperature of the precipitate-forming substitutional elements $(\mathrm{V}, \mathrm{Nb})$.

At the moment when precipitation starts, whatever the temperature $\left(\mathrm{P}_{\mathrm{s}}\right.$ curve $)$, it is assumed that the precipitated fraction corresponds to a value of $5 \%$. In the same way, when the $P_{f}$ curve is reached, the precipitated volume is close to $95 \%$. Once the $P_{f}$ curve has been reached, recrystallization starts to progress again due to fact that the pinning forces exerted by the precipitates are lower than the driving forces for recrystallization.

The RPTT diagrams, and especially the $\mathrm{P}_{\mathrm{s}}$ and $\mathrm{P}_{\mathrm{f}}$ curves, define a time interval, whatever the temperature, during which the precipitation state (size and precipitated volume) is changing. For times after $P_{f}$, the precipitated fraction does not vary but a coarsening of the precipitates occurs due to the effect of Ostwald ripening (Medina et al., 1999). For most of the steels, RPTT diagrams were determined for strains of 0.20 and 0.35 , as the strain is the most important variable for promoting strain-induced precipitation. The reheating temperature was normally $1200{ }^{\circ} \mathrm{C}$ for $\mathrm{V}$ microalloyed steels and somewhat higher for $\mathrm{Nb}$ microalloyed steels. In the former case it was seen that VN type particles were precipitated and in the case of steels containing $\mathrm{Nb}$, the precipitated particles were carbonitride types, and for this reason one of the prototypes with the highest probability of formation, $\mathrm{NbC}_{0.7} \mathrm{~N}_{0.2}$, was chosen (Turkdogan, 1989). 


\subsection{Types of precipitates and growing}

In microalloyed steels several types of precipitates depending if the steel contains vanadium, niobium or titanium, can be seen. The precipitates are generally $\mathrm{VN}, \mathrm{NbCN}$, TiN and AlN, respectively. When the steel contains more than one microalloying element, formation of mixed precipitates is possible.

The TEM resolution of vanadium nitrides corresponding to steel V4 was obtained on strained and quenched specimens at a time close to the start of the plateau. The carbon extraction replica technique was used. The electron energy dispersive X-Ray spectrum showed the presence of $\mathrm{V}$ and electron diffraction revealed a f.c.c. cubic lattice with a value of $\mathrm{a}=0.415 \mathrm{~nm}$, in accordance with the reference value found in the literature which is identified as vanadium nitride (Fig. 5).

Figure 6 shows precipitates in steel N4 and the spectrum showed the presence of $\mathrm{Nb}$ and the lattice parameter determined from Fig. $6 \mathrm{c}$ revealed a f.c.c. cubic lattice with a value of $\mathrm{a}=0.437 \mathrm{~nm}$ which is identified as vanadium carbonitride.

The start of the plateau is identified with the start of precipitation and its duration is related with two phenomena that take place simultaneously; namely increases in the precipitated volume and in the size of precipitates. Particle growth occurs by accretion of successive shells of nitrides or carbonitrides and each shell has its specific composition (Maugis and Gouné, 2005). When the precipitation is taking place, (a)

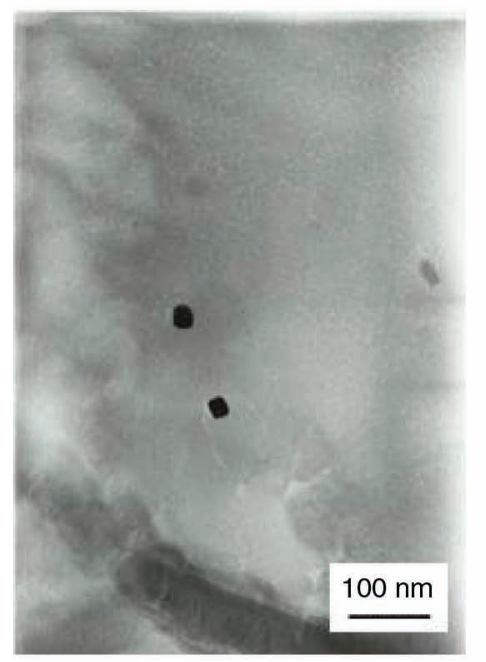

(b)

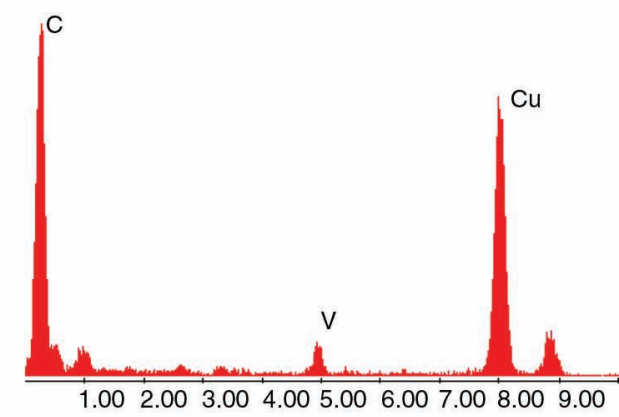

(c)

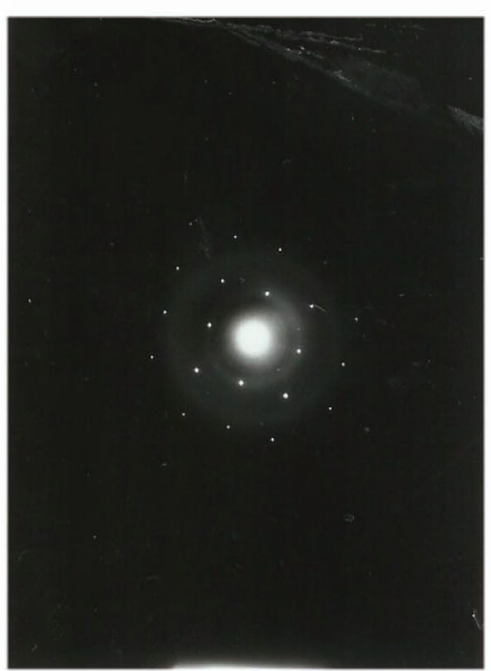

FIgURE 5. Transmission Electron Microscope (TEM) images of steel used: (a) image showing precipitates for specimen tested at reheating temp. $=1100^{\circ} \mathrm{C}$; deformation temperature $=850^{\circ} \mathrm{C}, \varepsilon=0.35, \dot{\varepsilon}=3.63 \mathrm{~s}^{-1} ; \mathrm{t}=25 \mathrm{~s}$;

(b) EDAX spectrum of precipitate and (c) electron diffraction image. 
(a)

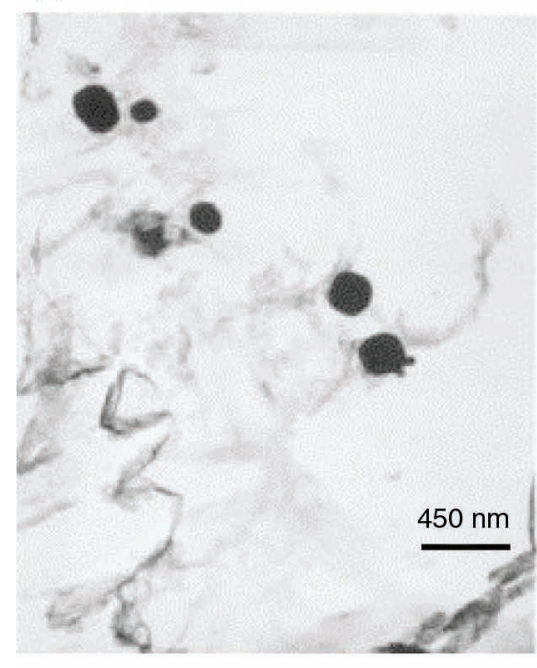

(b)

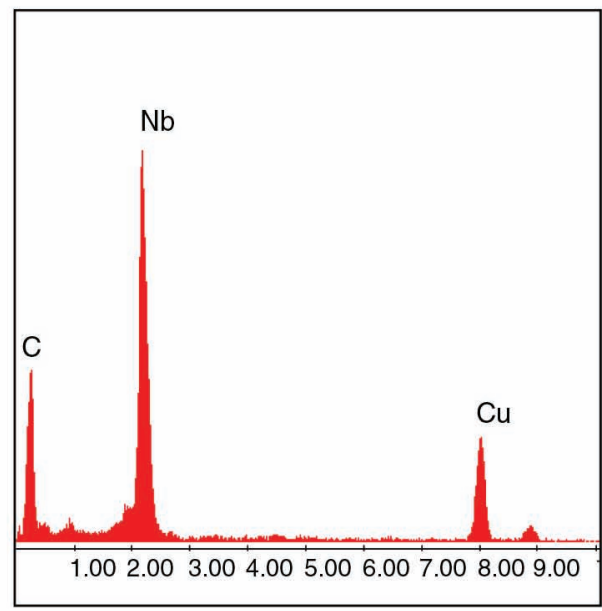

(c)

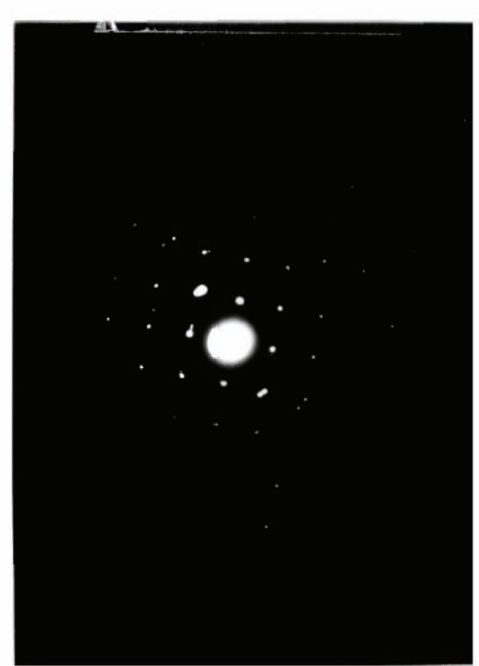

FIGURE 6. Transmission Electron Microscope (TEM) images of steel N4: (a) image showing precipitates for specimen tested at $1025^{\circ} \mathrm{C}, \varepsilon=0.35, \dot{\varepsilon}=3.63 \mathrm{~s}^{-1} ; \mathrm{t}=15 \mathrm{~s}$; (b) image showing precipitates for specimen tested at $1025^{\circ} \mathrm{C} \varepsilon=0.35$; $\dot{\varepsilon}=3.63 \mathrm{~s}^{-1} ; \mathrm{t}=100 \mathrm{~s} ;$ (c) EDAX spectrum of precipitate and (d) electron diffraction image.

it is assumed that particles growth occurs entirely by volume diffusion (Sun, 2005).

Dutta, Valdes and Sellars (Dutta et al., 1992) checked that the number of particles per unit volume decreased dramatically and this is not predicted by a simple growth model. Such a reduction in density of nucleation sites requires particle coarsening. The coarsening of precipitates by coalescence occurs once the precipitation is complete, i.e. when the plateau is finished and the recrystallization progresses again. The coalescence can be explained by the Modified Lifshitz-Slyozov-Wagner theory (MLSW) (Ardell1, 1972). This theory predicts that while the basic $\mathrm{t}^{1 / 3}$ kinetics of the LSW theory is maintained, the coarsening rate increases with an increase in the volume fraction, even at very small precipitated volume fraction values. According to the MLSW theory, the theoretical distribution of particle sizes broadens rapidly at small volume fraction values.

The evolution of the precipitate size was studied from the start of the plateau until after its end and the size distributions have served to confirm that the end of the plateau is due to the coarsening of precipitates and consequently to a decrease in pinning forces (Quispe et al., 2007; Medina et al., 2008b).

Precipitates TiN and AlN are of relatively large size and its impact on the recrystallization is very weak due to the large size of these precipitates. TiN precipitates are formed when the steel contains $\mathrm{Ti}$ and it takes place at high temperatures. AlN precipitates may form when the steel contains $\mathrm{Al}$ as a remain of deoxidation or the percentage of microalloying elements 
$(\mathrm{V}, \mathrm{Nb}, \mathrm{Ti})$ are relatively small leaving free nitrogen that could be combined with $\mathrm{Al}$ (Medina et al., 2010).

\section{MODEL OF STRAIN-INDUCED PRECIPITATION KINETICS}

\subsection{Precipitation start time}

In order to find the influence of every deformation variable, namely the strain $(\varepsilon)$, strain rate $\left(\dot{\varepsilon}\right.$, in $\left.\mathrm{s}^{-1}\right)$, austenite grain size $(\mathrm{D}$, in $\mu \mathrm{m})$ and the temperature ( $\mathrm{T}$, in $\mathrm{K}$ ), a new equation has been proposed based on Dutta and Sellars's expression (Dutta and Sellars, 1987) for a time corresponding to $5 \%$ of the precipitated volume $t_{0.05}$, which in practical terms can be taken as the nucleation time for precipitation:

$t_{0.05}=A \varepsilon^{-\beta} D^{s} Z^{r} \exp \left(\frac{Q_{d i f f}}{R T}\right) \exp \left[\frac{B}{T^{3}\left(\ln k_{s}\right)^{2}}\right]$

Equation (1) has been proposed because the results showed that the exponent of the strain $(\beta)$ is not a constant and is not equal to 1 but is dependent on the chemical composition, particularly on the microalloying element content. It was also seen that the austenite grain size (D) influences the parameter $t_{0.05}$. Furthermore, as will be seen below, the determination of the supersaturation ratio parameter $\left(k_{s}\right)$ was not a constant, and the mathematical expression found shows that it depends on the chemical composition of the steel, in particular the microalloying type and content. The use of nineteen steels with different $\mathrm{Nb}, \mathrm{V}$ and $\mathrm{Ti}$ contents allowed values and expressions to be found for the different parameters in Eq. (1) making it possible to predict with good approximation the experimental values found for $\mathrm{t}_{0.05}$.

Equation (1) also differs from the equation proposed by Sellars in the exponent $r$ of the ZenerHollomon parameter $\left(Z=\dot{\varepsilon} \exp \frac{Q_{d e f}}{R T}\right)$ which will be newly determined. The good approximation of the activation energy $\left(Q_{d}\right)$ to the energy for self-diffusion in $\mathrm{Fe}_{\gamma}$ indicates that the mechanism which governs the plastic flow of austenite is principally the climb of edge dislocations, which depends in turn on the diffusion of vacancies. The activation energy for the self-diffusion of iron in austenite varied with the presence of solutes, and the value of this variation depends on the atomic fraction of each solute, on its atomic volume, and on its heat sublimation. Therefore it seems logical to imagine that an increase in $Q_{d}$ would also raise the value of $t_{0.05}$.

The value of $\beta$ was calculated plotting $\ln t_{0.05}$ against $\ln \varepsilon$ (Fig. 7) and it was verified that its value is dependent on the content of $\mathrm{Nb}$ or $\mathrm{V}$. The expression resulting for $\beta$ was as follows:

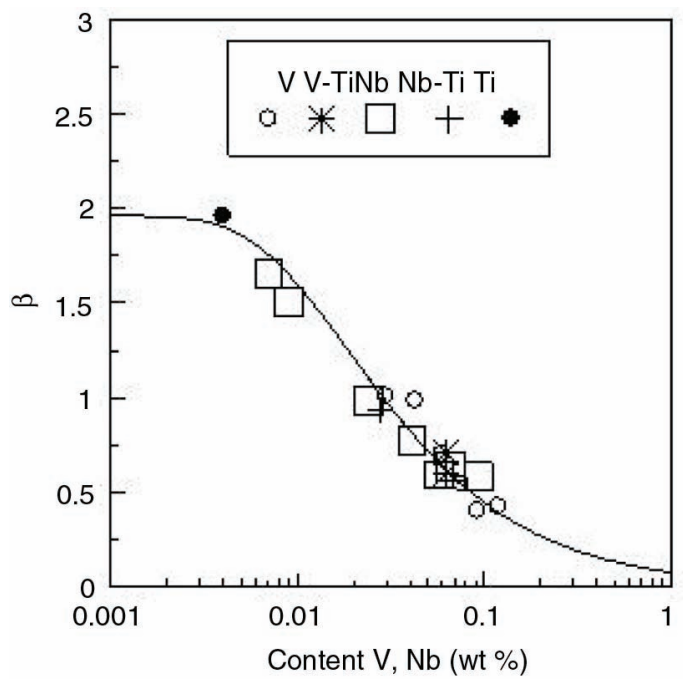

FIGURE 7. Plot of $\beta$ against the total microalloying element content (wt \%) $(\mathrm{V}, \mathrm{Nb})$.

$\beta=1.96\left[1-\exp \left(-3.994 \times 10^{-2}\left(\frac{1}{w}\right)^{0.813}\right)\right]$

where, $w$ is the percentage of $\mathrm{Nb}$ or $\mathrm{V}$.

If the steels contained both $\mathrm{Nb}$ and $\mathrm{V}$, the parameter $w$ will take account only of $\mathrm{Nb}$ percentage, as the $\mathrm{Nb}$-carbonitrides would precipitate before than V-nitrides or V-carbides. Equation (2) means that the strain starts to influence the precipitation kinetics when the microalloy content is less than a certain amount, which in practical terms could be approximately 0.3 (wt \%). Below this content the value of $\beta$ begins to be more than zero and consequently the strain starts to affect the precipitation kinetics. On the other hand, the value of exponents " $r$ " was determined plotting $\ln t_{0.05}$ against $\ln \mathrm{Z}$, and the value of 0.20 was found. Concerning to the value of exponent " $s$ " of grain size, it was determined representing $\operatorname{lnt} t_{0.05}$ against $\ln D$, obtaining the value of 0.48 close to 0.5 .

The activation energy $\left(Q_{d e f}\right)$ for hot deformation is expressed as a function of the chemical composition of the steel and is as follows (Medina et al., 2014a):

$$
\begin{aligned}
Q_{d e f}\left(\mathrm{~J} . ~ m o l^{-1}\right) & =267000-2535.52[\mathrm{C}]+1010[\mathrm{Mn}] \\
& +33620.76[\mathrm{Si}]+70729.85[\mathrm{Nb}]^{0.565} \\
& +31673.46[\mathrm{~V}]+93680.52[\mathrm{Ti}]^{0.5919}
\end{aligned}
$$

The activation energy for bulk diffusivity $\left(Q_{\text {diff }}\right)$ of $\mathrm{Nb}$ and $\mathrm{V}$ atoms in $\mathrm{Fe}_{\gamma}$, respectively, are given by:

Nb-steels: $Q_{\text {diff }}=270000 \mathrm{~J} \mathrm{~mol}^{-1}$ V-steels: $Q_{\text {diff }}=264000 \mathrm{~J} \mathrm{~mol}^{-1}$ 
According to Turkdogan, the supersaturation ratio defined by $k_{s}$ will be (Turkdogan, 1989):

Nb-Steels:

$k_{s}=\frac{[N b][C]^{0.7}[N]^{0.2}}{\left[10^{4.12-\frac{9450}{T}}\right]}$

V-Steels:

$k_{s}=\frac{[V][N]}{\left[10^{2.86-\frac{7700}{T}}\right]}$

The next expression is deduced (Medina et al., 2014a):

$T_{N}=T_{s}-\Delta T_{N}$

where, $T_{s}$ is the solubility temperature and $T_{N}$ is the nose temperature of the precipitation start curve $\left(\mathrm{P}_{\mathrm{s}}\right)$. The expressions for $T_{s}$ are as follows (Turkdogan, 1989):

V-Steels:

$T_{s}=\frac{7700}{2.86-\log \left(V^{0} \%\right)\left(N^{\%}\right)}$

Nb-Steels:

$T_{s}=\frac{9450}{4.12-\log (N b \%)(C \%)^{0.7}(N \%)^{0.2}}$

The next expressions were found (Medina et al., 2014a):

V-Steels:

$\Delta T_{N}=176.1\left[X_{i}\right]^{0.382}$

$\mathrm{Nb}-$ Steels:

$\Delta T_{N}=139\left[X_{i}\right]^{0.283}$

V-Ti; Nb-Ti Steels:

$\Delta T_{N}=118\left[X_{i}\right]^{0.293}$

In the case of $\mathrm{V}$-steels, $X_{i}$ is $(\mathrm{V} \%)(\mathrm{N} \%) \times 10^{3}$ and in the case of $\mathrm{Nb}$-steels it should be $(\% \mathrm{Nb})(\% \mathrm{C})^{0.7}$ $(\% \mathrm{~N})^{0.2} \times 10^{3}$.

The parameter $B$ depends on the supersaturation ratio $k_{s}$ calculated for the nose temperature $\left(\mathrm{T}_{\mathrm{N}}\right)$ of
RPTT diagram and taking into account the chemical composition of each steel. In this way, an expression for $B$ was obtained:

$B\left(K^{3}\right)=4.238 \times 10^{8} \exp \left(1.689 \ln K_{s}\right)$

Equation (12) is valid for all the microalloyed steels with $\mathrm{V}$ or $\mathrm{Nb}$ including the steels that contain $\mathrm{Ti}$ in addition to these elements. In the latter case, $k_{s}$ would be calculated by reducing the nitrogen percentage that has combined with Ti. In agreement with Eq. (12) the $B$ values calculated for the studied steels are approximately between $2 \times 10^{9}$ and $7 \times 10^{10} \mathrm{~K}^{3}$.

Coefficient $A$ was seen to be a function of the saturation ratio $k_{s}$ defined by expressions (4) and (5) and the following relationships were deduced:

V-Steels:

$A\left(s^{-1}\right)=3.142 \times 10^{-10} \exp \left(-1.20 \ln K_{s}\right)$

Nb-Steels:

$A\left(s^{-1}\right)=4.766 \times 10^{-11} \exp \left(-0.07 \ln K_{s}\right)$

V-Ti and Nb-Ti Steels:

$A\left(s^{-1}\right)=4.13 \times 10^{-10} \exp \left(-0.47 \ln K_{s}\right)$

The $t_{0.05}$ times calculated according to expression (1) and all the corresponding parameters were compared with the experimental $t_{0.05}$ times, finding a good correlation between both sets of values (Fig. 8). Some relevant dispersion is observed in some $\mathrm{Nb}$ steels, which is probably due to the formation of $\mathrm{Nb}(\mathrm{C}, \mathrm{N})$ precipitates with a different stoichiometric ratio between C and N (Medina and Quispe, 2000).

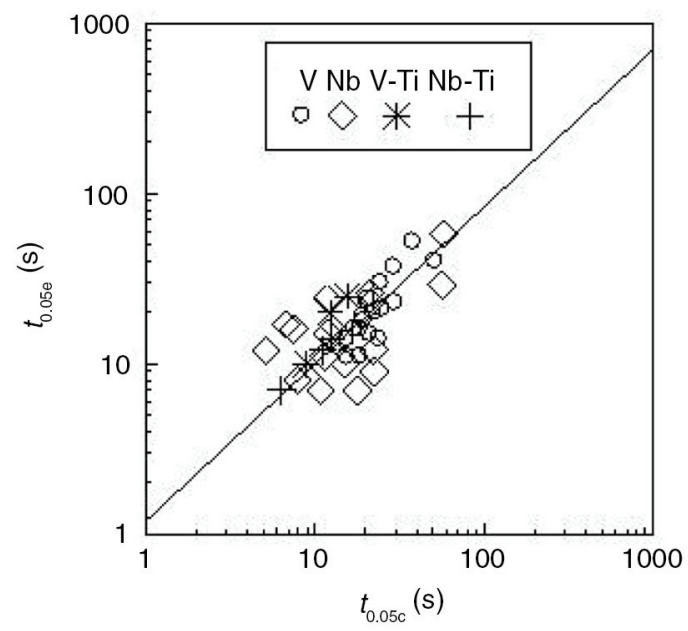

FIGURE 8. Experimental versus calculated parameter $t_{0.05}$. 


\subsection{Precipitation kinetics in isothermal conditions}

As occurs in other physical phenomena, where a nucleation time is necessary for the phenomenon to start, precipitation obeys Avrami's law and the precipitated fraction can be expressed in the following way (Maugis and Gouné, 2005):

$X_{p}=1-\exp \left[\ln 0.95\left(\frac{t}{t_{0.05}}\right)^{n}\right]$

where $n$ is a constant and $t_{0.05}$ is given by Eq. (1).

If in equation (16), $X_{p}=0.95$, the following expression is found:

$t_{0.95}=\left(\frac{\ln 0.05}{\ln 0.95}\right)^{1 / n} t_{0.05}=(58.4)^{1 / n} t_{0.05}$

Expression (17) can be used to determine the value of $n$, since the times $t_{0.05}$ and $t_{0.95}$ are determined experimentally. The regression of the values of $t_{0.95}$ to $t_{0.05}$ gave the following equations:

V and V-Ti Steels:

$t_{0.95}=7.26\left(t_{0.05}\right)^{0.999}$

$\mathrm{Nb}$ and $\mathrm{Nb}-\mathrm{Ti}$ Steels:

$t_{0.95}=14.15\left(t_{0.05}\right)^{1.001}$

Expressions (18) and (19) indicate that strain-induced precipitation obeys Avrami's law, as in both cases the exponent of parameter $t_{0.05}$ is close to 1 , according to expression (17).

By comparing Eqs. (17-19) the following values for $n$ were obtained:

V and V-Ti Steels: $n=2.05$; $\mathrm{Nb}$ and Nb-Ti Steels: $n=1.54$

By replacing $t_{0.05}$ from Eq. (1) and the values of 2.05 and 1.54 for $n$ in Eq. (16), two models of straininduced precipitation kinetics were finally obtained for $\mathrm{V}$-steels and $\mathrm{Nb}$-steels, respectively, in isothermal conditions. Fig. 9 shows the prediction of the model in a random example, showing the good concordance between the experimental and calculated $\mathrm{P}_{\mathrm{s}}$ and $\mathrm{P}_{\mathrm{f}}$ curves, respectively.

\subsection{Precipitation kinetics in continuous cooling conditions}

From Eq. (16), the expression resulting for cooling conditions, applying the method known as "compensated times", is as follows:

$X_{p}=1-\exp \left[\ln 0.95\left(\int_{0}^{t} \frac{d t}{t_{0.05}^{*}}\right)^{n}\right]$

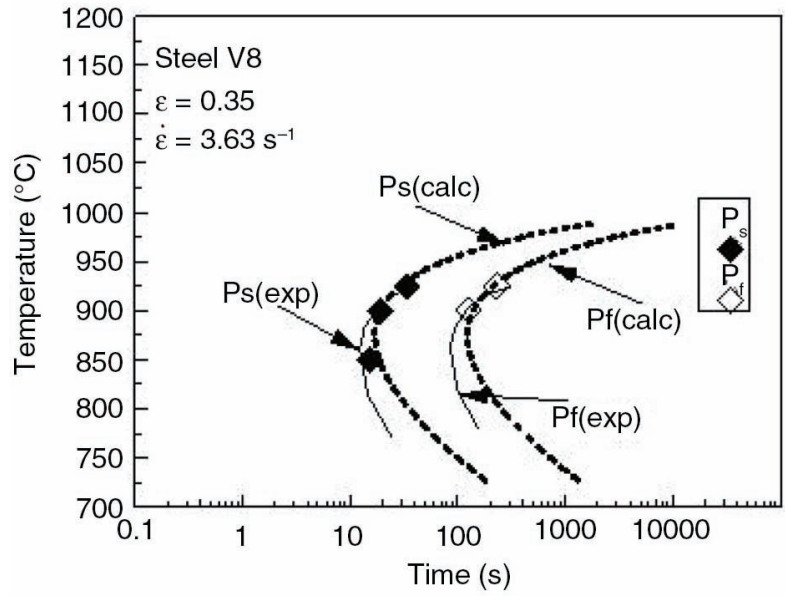

FIGURE 9. Experimental and calculated $\mathrm{P}_{\mathrm{s}}$ and $\mathrm{P}_{\mathrm{f}}$ curves for steel $\mathrm{V} 8$.

$t_{0.05}$ is given by the Eq. (1), where $\mathrm{T}$ should be replaced by $\left(\mathrm{T}_{\mathrm{D}}-\mathrm{vt}\right)$, being:

$T_{D}=$ deformation temperature (pass temperature, $\mathrm{K}$ ); $v=$ cooling rate $\left(\mathrm{Ks}^{-1}\right) ; \mathrm{t}=$ time $(\mathrm{s})$

Some examples on the precipitated fraction against the time for isothermal conditions and for cooling conditions are showed in Figs. 10 and 11, respectively. It is observed that if the steel V5 was deformed applying a strain of 0.35 at $1150 \mathrm{~K}\left(877^{\circ} \mathrm{C}\right)$, the precipitation should be approximately finished in $150 \mathrm{~s}$ for isothermal conditions, but for cooling conditions at cooling rate of $1 \mathrm{~K} \mathrm{~s}^{-1}$ the precipitation should never be completed (Fig. 10), being in this case the maximum precipitated fraction of $80 \%$. When the strain temperature is reduced at $1113 \mathrm{~K}\left(840{ }^{\circ} \mathrm{C}\right)$, the precipitated fraction for cooling conditions cannot exceed the $50 \%$ and a plateau, as in the last case, is observed (Fig. 11). These results are very important and they show that the cooling conditions could avoid the precipitation was completed.

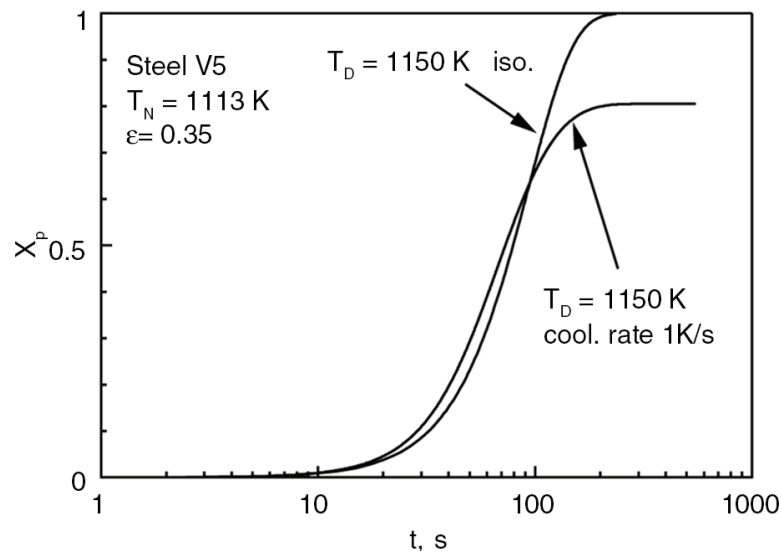

Figure 10. Precipitated fraction (Xp) against time. Isothermal and cooling conditions. Steel V5. (T=1150 K). 


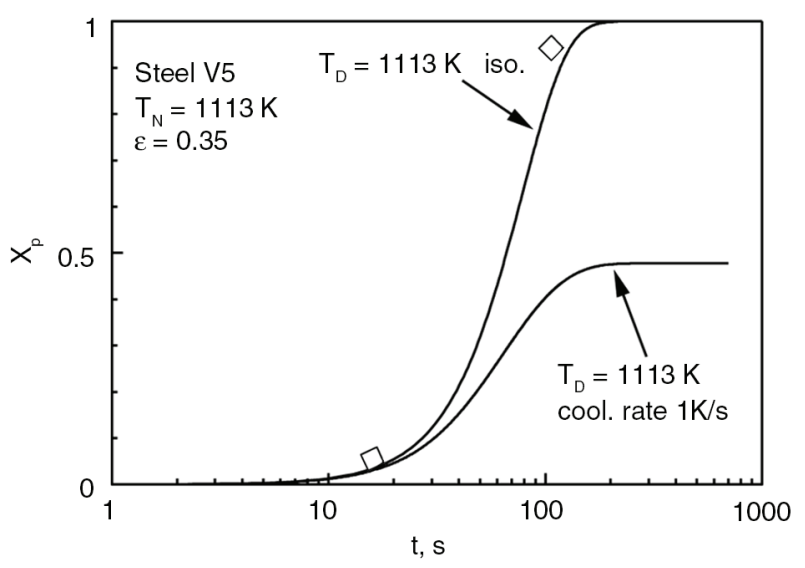

FIGURE 11. Precipitated fraction (Xp) against time. Isothermal and cooling conditions. Steel V5. (T=1113 K).

\section{CONCLUSIONS}

- A new model for strain-induced precipitation in microalloyed steels has been constructed.

- At greater strains, the times for the incubation of the precipitates and for complete precipitation are smaller.

- For larger austenite grain sizes, the times for incubation of the precipitates and complete precipitation are also longer.

- The model on precipitation kinetics was constructed in isothermal conditions and converted at cooling rate conditions applying the method known as "compensated times".

- The cooling conditions could avoid that the precipitation was completed.

- The incubation time $\left(t_{0.05}\right)$ for precipitation decreases as the microalloying element content increases, but does not depend on the nature of the precipitates.

- The parameter $B$ depends on the supersaturation ratio $k_{s}$ calculated for the nose temperature $\left(\mathrm{T}_{\mathrm{N}}\right)$. The $B$ values calculated for the studied steels are approximately between $3.6 \times 10^{9}$ and $7.2 \times 10^{10} \mathrm{~K}^{3}$.

- Strain-induced precipitation kinetics obey Avrami's law, where the time necessary for precipitation to finalize $\left(t_{0.95}\right)$ is linearly related to the incubation time $\left(t_{0.05}\right)$.

\section{REFERENCES}

Andrade, H.L., Akben, M.G., Jonas, J.J. (1983). Effect of molybdenum, niobium, and vanadium on static recovery and recrystallization and on solute strengthening in microalloyed steels. Metall. Trans. A 14 (10), 1967-1977. http:// dx.doi.org/10.1007/BF02662364.

Ardell, J. (1972). The effect of volume fraction on particle coarsening: theoretical considerations. Acta Metall. 20 (1), 61-71. http://dx.doi.org/10.1016/0001-6160(72)90114-9.

Dutta, B., Sellars, C.M. (1987). Effect of composition and process variables on $\mathrm{Nb}(\mathrm{C}, \mathrm{N})$ precipitation in niobium microalloyed austenite. Mater. Sci. Technol. 3 (3), 197-207. http://dx.doi.org/10.1179/026708387790122846.
Dutta, B., Valdes, E., Sellars, C.M. (1992). Mechanisms and kinetics of strain induced precipitation of $\mathrm{Nb}(\mathrm{C}, \mathrm{N})$ in austenite. Acta Metall. Mater. 40 (4), 653-662. http://dx.doi. org/10.1016/0956-7151(92)90006-Z.

Faessel, A. (1976). La Simulation du Laminage par l'essai de Torsión. Rev. Métall. Cah. Inf. Tech. 33 (4), 875-892.

Galán, J., Samek, L., Verleysen, P., Verbeken, K., Houbaert, Y. (2012). Advanced high strength steels for automotive industry. Rev. Metal. 48 (2), 118-131. http://dx.doi.org/ 10.3989/revmetalm.1158.

Gladman, T. (1997). The Physical Metallurgy of Microalloyed Steels. The Institute of Materials, London.

Gómez, M., Medina, S.F., Quispe, A., Valles, P. (2002). Static Recrystallization and Induced Precipitation in a Low Nb Microalloyed Steel. ISIJ Int. 42 (4), 423-431. http://dx.doi. org/10.2355/isijinternational.42.423.

Gómez, M., Medina, S.F., Valles, P. (2005). Determination of driving and pinning forces for static recrystallization during hot rolling of a Nb-microalloyed steel. ISIJ Int. 45(11), 1711-1720. http://dx.doi.org/10.2355/isijinternational.45.1711.

Gómez, M., Rancel, L., Medina, S.F. (2009). Effects of Aluminium and nitrogen on static recrystallizationin V-microalloyed steels. Mater. Sci. Eng. A 506 (1-2), 165-173. http://dx.doi. org/10.1016/j.msea.2008.11.049.

Kwon, O. (1992). A Technology for the Prediction and control of microstructural changes and mechanical properties in Steel. ISIJ Int. 32 (3), 350-358. http://dx.doi.org/10.2355/ isijinternational.32.350.

Kwon, O., DeArdo, A.J. (1991). Interactions between recrystallization and precipitation in hot-deformed microalloyed steels. Acta Metall. Mater. 39 (4), 529-538. http://dx.doi. org/10.1016/0956-7151(91)90121-G.

Luton, M.J., Dorvel, R., Petkovic, R.A. (1980). Interaction between deformation, recrystallization and precipitation in niobium steels. Metall. Trans. A 11 (3), 411-420. http:// dx.doi.org/10.1007/BF02654565.

Maugis, P., Gouné, M. (2005). Kinetics of vanadium carbonitride precipitation in steel: A computer model. Acta Mater. 53 (12), 3359-3367. http://dx.doi.org/10.1016/j.actamat.2005. 03.036 .

Medina, S.F., Mancilla, J.E. (1994).The Influence of Titanium on the Static Recrystallization of Hot Deformed Austenite and on Induced Precipitation Kinetics. Scripta Metall. Mater. 30 (1), 73-78. http://dx.doi.org/10.1016/0956-716X (94)90361-1.

Medina, S.F., Quispe, A., Valles, P., Baños, J.L. (1999). Recrystallization-Precipitation Interaction Study of Two Medium Carbon Niobium Microalloyed Steels. ISIJ Int. 39 (9), 913-922. http://dx.doi.org/10.2355/isijinternational. 39.913.

Medina, S.F., Vega, M.I., Chapa, M. (2000). Critical Cooling Temperatures $\left(\mathrm{T}_{\mathrm{nr}}, \mathrm{A}_{\mathrm{r} 3}, \mathrm{~A}_{\mathrm{r} 1}\right)$ and Phase Transformation Kinetics in Structural Steels Determined by Mean Flow Stress and Dilatometry. Mater. Sci. Technol. 16 (2), 163-170. http://dx.doi.org/10.1179/026708300101507659.

Medina, S.F., Quispe, A. (2000). Influence of strain rate on recrystallization-precipitation interaction in $\mathrm{V}, \mathrm{Nb}, \mathrm{V}-\mathrm{Ti}$ microalloyed steels. Mater Sci. Technol. 16 (6), 635-642. http://dx.doi.org/10.1179/026708300101508405.

Medina, S.F., Gómez, M., Rancel, L. (2008a). Grain refinement by intragranular nucleation of ferrite in a high nitrogen vanadium microalloyed steel. Scripta Mater. 58 (2), 1110-1113 http://dx.doi.org/10.1016/j.scriptamat.2008.02.004.

Medina, S.F., Rancel, L., Gómez, M., Ishak, R., de Sanctis, M. (2008b). Intragranular nucleation of ferrite on precipitates and grain refinement in a hot deformed V-microalloyed steel. ISIJ Int. 48 (11), 1603-1608. http://dx.doi.org/10.2355/ isijinternational.48.1603

Medina, S.F., Gómez, M., Valles, P., Gómez, P.P. (2010). Effects of TiN and AlN nanoparticles in Hot Deformation of Austenite in Steels. Steel Res. Int. 81 (11), 1010-1015. http://dx.doi.org/10.1002/srin.201000045.

Medina, S.F., Quispe, A., Gómez, M. (2014a). Model for strain induced precipitation kinetics in microalloyed steels. Metall. Mater. Trans. $A 45$ (3), 1524-1539. http://dx.doi.org/10.1007/ s11661-013-2068-1. 
Medina, S.F., Quispe, A., Gómez, M. (2014b). Erratum to: Model for strain-induced precipitation kinetics in microalloyed steels. Metall. Mater. Trans. A 45 (6), 2925-2925. http:// dx.doi.org/10.1007/s11661-014-2297-y.

Mintz, B., Arrowsmith, J.M. (1980). Influence of microalloting additions on hot ductility of steels in, C.M. Sellars and G.J. Davies (Ed.), Proc. Int. Conf. on Hot Working and Forming Processes, Metal Society, London, 99-103.

Perttula, J.S., Karjalainen, L.P. (1998). Recrystallizationrates in austenite measured by double compression and stress relaxation methods. Mater. Sci. Technol. 14 (7), 626-630. http://dx.doi.org/10.1179/026708398790290578.

Quispe, A., Medina, S.F., Valles, P. (1997). Recrystallizationinduced precipitation interaction in a medium carbon vanadium microalloyed steel. ISIJ Int. 37 (8), 783-788. http:// dx.doi.org/10.2355/isijinternational.37.783.
Quispe, A., Medina, S.F., Gómez, M., Chaves, J.I. (2007). Influence of austenite grain size on recrystallizationprecipitation interaction in a V-microalloyed steel. Mater. Sci. Eng. A 447 (1-2), 11-18. http://dx.doi.org/10.1016/j. msea.2006.11.036.

Sun, W. (2005). Particle coarsening: I. Kinetics for reversible issolution/deposition controlled process. Acta Mater. 53 (11), 3329-3334. http://dx.doi.org/10.1016/j.actamat.2005.03.050.

Turkdogan, E.T. (1989). Causes and effects of nitride and carbonitride precipitation during continuous casting. Iron Steel Making. 16, 61-75.

Vega, M.I., Medina, S.F., Chapa, M., Quispe, A. (1999). Determination of Critical Temperatures $\left(\mathrm{T}_{\mathrm{n},}, \mathrm{A}_{\mathrm{r} 3}, \mathrm{~A}_{\mathrm{r} 1}\right)$ in Hot Rolling Structural Steels with Different Ti and N Contents. ISIJ Int. 39 (12), 1304-1310. http://dx.doi.org/10.2355/ isijinternational.39.1304. 